\title{
Comparative Study of 1.5-Hour and 48-Hour Homologous Passive Cutaneous Anaphylaxis in the Mouse Ear
}

\author{
Naoki INAGAKI, Hiroichi NAGAI, Ichiro NAKATOMI, and Akihide KODA \\ Department of Pharmacology, Gifu Pharmaceutical University, 5-6-1, Mitahora-higashi, Gifu, 502, \\ Japan
}

(Received July 13, 1987)

\begin{abstract}
To characterize passive cutaneous anaphylaxis (PCA) in the mouse ear, reactions caused by non-heated and heated antiserum were compared to those caused by monoclonal immunoglobulin $\mathrm{E}$ antibody (mc-IgE) and monoclonal immunoglobulin $\mathrm{G}_{1}$ antibody (mc- $\mathrm{IgG}_{1}$ ). Heat treatment at $56{ }^{\circ} \mathrm{C}$ did not alter the activity of antiserum or $\mathrm{mc}-\mathrm{IgG}_{1}$ to elicit the 1.5-h PCA. The 1.5-h PCA mediated by mc-IgE and 48-h PCA's mediated by both antiserum and mc-IgE were abrogated almost completely

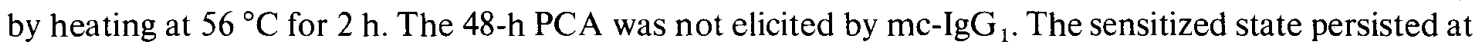
least for $7 \mathrm{~d}$ when mice were sensitized with non-heated antiserum or mc- $\operatorname{lgE}$. In contrast, the sensitized state disappeared rapidly in cases of heated antiserum and $\mathrm{mc}^{-I_{g G}} \mathrm{G}_{1}$. In 48-h PCA's mediated by antiserum and $\mathrm{mc}-\mathrm{IgE}$, extravasated dye in the ear was detected $5 \mathrm{~min}$ after challenge and the reaction was terminated in $15 \mathrm{~min}$. In contrast, in the 1.5-h PCA mediated by heated antiserum, the accumulation of dye in the ear was delayed slightly when compared to the 48 -h PCA. In mc-IgG $_{1}-$ mediated 1.5-h PCA, the delay was significant. Both 1.5-h PCA's mediated by heated antiserum and $\mathrm{mc}^{-\operatorname{IgG}_{1}}$, and the 48-h PCA's mediated by antiserum and mc-IgE were not observed in WBB6 $\mathrm{F}_{1}-\mathrm{W} / \mathrm{W}^{\mathrm{v}}$ mice, which lack mast cells. All these PCA's were inhibited equally by tranilast, an inhibitor of mediator release from mast cells. The 1.5-h PCA was abrogated completely when heated antiserum was absorbed with a rabbit anti-mouse IgG $_{1}$ serum coupled-Sepharose $4 \mathrm{~B}$. On the other hand, the 48-h PCA was abrogated completely by absorption of the antiserum with goat anti-mouse IgE serum coupledSepharose 4B. These results indicated that the 48-h PCA in mice sensitized with antiserum is mediated by $\operatorname{IgE}$ antibody. In the 1.5-h PCA in mice sensitized with heated antiserum, it is considered that $\operatorname{IgG}_{1}$ antibody plays a major role to elicite PCA. However, it is also considered that the reaction is modified by other serum components.
\end{abstract}

Keywords - mouse ear passive cutaneous anaphylaxis; $\operatorname{IgE}$ antibody; $\operatorname{IgG}_{1}$ antibody; monoclonal $\mathrm{IgE}$ antibody; monoclonal $\mathrm{IgG}_{1}$ antibody; heat-treatment

\section{Introduction}

Experimental animals produce 2 types of homocytotropic antibodies which are detectable by passive cutaneous anaphylaxis (PCA). ${ }^{1-7)}$ One is immunoglobulin E ( $\operatorname{IgE}$ ) antibody and the other belongs to the immunoglobulin $\mathrm{G}$ (IgG) class and these antibodies are characterized by their thermostability and causing a persistence of the sensitized state of the skin. The IgE antibody is important in type I allergyrelated diseases in man and the mechanism of the allergic reaction caused by $\mathrm{IgE}$ antibody has studied in detail. ${ }^{8-10)}$ IgG homocytotropic antibody in man belongs to the $\operatorname{IgG}_{4}$ subclass and the blocking activity is attributed to this subclass. ${ }^{11}$ However, the mechanism of IgG homocytotropic antibody-mediated reaction is not fully elucidated. In mice, the $\operatorname{IgG}_{1}$ subclass corresponds to human $\mathrm{IgG}_{4}$ subclass and acts as homocytotropic antibody.

Mouse ear is a useful site to study PCA ${ }^{12-14)}$ and we have used the ear in a method for quantitative evaluation of homologous PCA using sensitizing period of $48 \mathrm{~h}$ (48-h PCA). ${ }^{14-16)}$ In these reports, we confirmed that the 48-h PCA elicited in the mouse ear is highly responsive and reproducible. On the other hand, mouse $\mathrm{IgG}_{1}$ antibody is detected using sensitizing period of $1.5 \mathrm{~h}$ in the homologous PCA (1.5-h PCA). ${ }^{17)}$ In the present study, a comparison of 1.5-h and 48-h PCA's caused by antiserum, monoclonal IgE antibody (mc-IgE) and monoclonal $\operatorname{IgG}_{1}$ antibody $\left(\mathrm{mc}-\mathrm{IgG}_{1}\right.$ ) in the mouse ear was undertaken. 


\section{Materials and Methods}

Mice - Female BALB/c mice which were 8 weeks old were used for the preparation of antiserum. Male ddY, WBB6 $\mathrm{F}_{1^{-}}+/+$and WBB6 $\mathrm{F}_{1}-\mathrm{W} / \mathrm{W}^{\mathrm{v}}$ mice of 7 weeks old were used as recipients for PCA. All mice were purchased from Shizuoka Laboratory Animal Center (Shizuoka, Japan).

Antigens - Dinitrophenylated Ascaris suum extract (DNP-As) and bovine serum albumin (DNP-BSA) were prepared according to the method of Eisen et al. ${ }^{18)}$ Human IgG (HIG) was purchased from Miles Laboratories, Inc. (Naperville, USA).

Antiserum and Monoclonal Antibodies - Antiserum was prepared as follows. BALB/c mice were immunized twice or thrice with $10 \mu \mathrm{g}$ of DNP-As and $1 \mathrm{mg}$ of alum intraperitoneally at intervals of $30 \mathrm{~d}$. Serum was obtained $7-10 \mathrm{~d}$ after the last immunization and pooled. The antiserum was lyophilized and stored at $-20^{\circ} \mathrm{C}$. The 48-h PCA titer of the antiserum, estimated in the mouse ear (mouse ear PCA, see below), was $1: 512$. The 1.5 -h PCA titer of heated (at 56 ${ }^{\circ} \mathrm{C}$ for $2 \mathrm{~h}$ ) antiserum in the mouse ear was 1 : 1024. The PCA titer estimated in the rat (Wistar, sensitizing period: $24 \mathrm{~h}$, challenging antigen: $1 \mathrm{mg}$ of DNP-BSA) was $1: 2048$.

Anti-DNP monoclonal IgE antibody (mc$\mathrm{IgE})$, prepared in ascites fluid of $\mathrm{BALB} / \mathrm{c} \times$ C57BL/6 $\mathrm{F}_{1}$ mice, was purchased from Serotec, Ltd. (Bicester, UK). The 48-h PCA titer of mc-IgE estimated in the mouse ear was $1: 2000$. The PCA titer estimated in the rat (Wistar, sensitizing period: $24 \mathrm{~h}$, challenging antigen: $1 \mathrm{mg}$ of DNP-BSA) was $1: 5000-8000$.

Anti-HIG monoclonal $\operatorname{IgG}_{1}$ antibody $\left(\mathrm{mc}-\mathrm{IgG}_{1}\right)$, prepared in ascites fluid of BALB/c mice, was obtained from Miles Laboratories, Inc. (Naperville, USA). The 1.5-h PCA titer of heated (at $56^{\circ} \mathrm{C}$ for $2 \mathrm{~h}$ ) $\mathrm{mc}^{-\mathrm{IgG}_{1}}$ estimated in the mouse ear was 1:5000. The 50 -fold diluted mc-IgG ${ }_{1}$ did not evoke PCA in rats (Wistar, sensitizing period: $24 \mathrm{~h}$, challenging antigen: $1 \mathrm{mg}$ of HIG).

To evaluate the effect of heating on PCA, antiserum and monoclonal antibodies were heated at $56{ }^{\circ} \mathrm{C}$ for $0.5-2 \mathrm{~h}$ before dilution.
Absorption of Antiserum - Rabbit antimouse IgG $_{1}$ serum $\left(\gamma_{1}\right.$-specific, Litton Bionetics, Charleston, USA) or goat anti-mouse IgE serum ( $\epsilon$-specific, Miles Laboratories, Naperville, USA) was coupled to $\mathrm{CNBr}$-activated $\mathrm{Se}$ pharose 4B (Pharmacia, Uppsala, Sweden). Non-heated or heated antiserum was rotated gently with anti-mouse $\operatorname{IgG}_{1}$ serum-coupled Sepharose 4B (anti- $\gamma_{1}-$ Sepharose 4B) or antimouse IgE serum-coupled Sepharose 4B (anti$\epsilon$-Sepharose $4 B$ ) for $30 \mathrm{~min}$ at room temperature and filtered on a glass filter (G3). Each filtrate was concentrated and adjusted to an appropriate volume required for sensitization.

Mouse Ear PCA — Mouse ear PCA was carried out according to the method described previously. ${ }^{15,16)}$ Briefly, $10 \mu$ l of diluted antiserum or monoclonal antibody were injected into both sides of ears of ether anesthesized mice. After 1.5 or $48 \mathrm{~h}$, PCA was elicited by an intravenous injection of $0.25 \mathrm{mg}$ of antigen (DNP-BSA or HIG) dissolved in $0.5 \%$ Evans blue saline solution in a volume of $0.25 \mathrm{ml}$. Thirty min after the challenge, mice were sacrificed by cervical dislocation and ears were removed. To measure the amount of dye detected nonspecifically, nonsensitized mice received a similar antigenic challenge and results were indicated as $\mathrm{PCA}(-)$. In one experiment, the sensitizing period was varied from $1.5 \mathrm{~h}$ to $7 \mathrm{~d}$. In another experiment, to examine the accumulation of dye in the ear, mice were sacrificed $2-40 \mathrm{~min}$ after the challenge.

The amount of dilutions used for antiserum (30- or 40-fold), mc-IgE (500-fold) and $\mathrm{mc}^{-\mathrm{IgG}_{1}}$ (1 000-fold) depended upon the results of preliminary experiments. The amounts of dye leaked at these dilutions in the preliminary experiments were as follows: heated antiserum $(\times 40), 19.24 \pm 1.58 \mu \mathrm{g}(n=8,1.5$-h PCA $)$; non-heated antiserum $(\times 30), 19.87 \pm 1.73 \mu \mathrm{g}$ $(n=8,48-\mathrm{h}$ PCA $)$; mc-IgE, $13.82 \pm 1.64 \mu \mathrm{g}$ $(n=5,48$-h PCA); mc-IgG $1,18.24 \pm 2.88 \mu \mathrm{g}$ $(n=5,1.5$-h PCA).

Tranilast, an anti-allergic agent, ${ }^{19,20)}$ was obtained from Kissei Pharmaceutical Co., Ltd. (Matsumoto, Japan). Tranilast was suspended in distilled water containing $0.2 \%$ sodium carboxymethylcellulose and given orally $1 \mathrm{~h}$ prior 
to antigenic challenge. In this experiment, mice were fasted for $6-8 \mathrm{~h}$ before the administration.

Measurement of Dye - Extraction and measurement of extravasated dye were performed according to the method described previously. ${ }^{15.16)}$ A pair of ears were dissolved with $0.7 \mathrm{ml}$ of $1 \mathrm{~N} \mathrm{KOH}$ solution in a stoppered tube at $37^{\circ} \mathrm{C}$ overnight and $9.3 \mathrm{ml}$ of a mixture of $0.6 \mathrm{~N} \mathrm{H}_{3} \mathrm{PO}_{4}$ solution and acetone $(5: 13)$ was added. After vigorous shaking, precipitates were filtered off and the amount of dye was measured colorimetrically at $620 \mathrm{~nm}$.

Statistical Analysis — Each value of the results is presented as the mean and the standard error. The difference between two groups was evaluated statistically by the Student's $t$ test.

\section{Results}

\section{Effect of Heat-Treatment}

Effects of heat-treatment of antiserum or monoclonal antibodies on 1.5-h and 48-h PCA's were investigated. Antiserum, mc-IgE and mc-IgG ${ }_{1}$ were heated at $56^{\circ} \mathrm{C}$ for $0.5,1$ or $2 \mathrm{~h}$. Results are shown in Fig. 1. In the case of antiserum, heating did not affect the 1.5-h PCA. However, the 48-h PCA was reduced in proportion to the heating time. On the other hand, both PCA's mediated by mc-IgE were reduced in proportion to heating time similar to the 48-h PCA mediated by antiserum. Although the $1.5-\mathrm{h}$ PCA mediated by $m c-\operatorname{IgG}_{1}$ was not affected by heating like that mediated by antiserum, the 48-h PCA was not elicited by $\mathrm{mc}^{-\mathrm{IgG}_{1}}$.

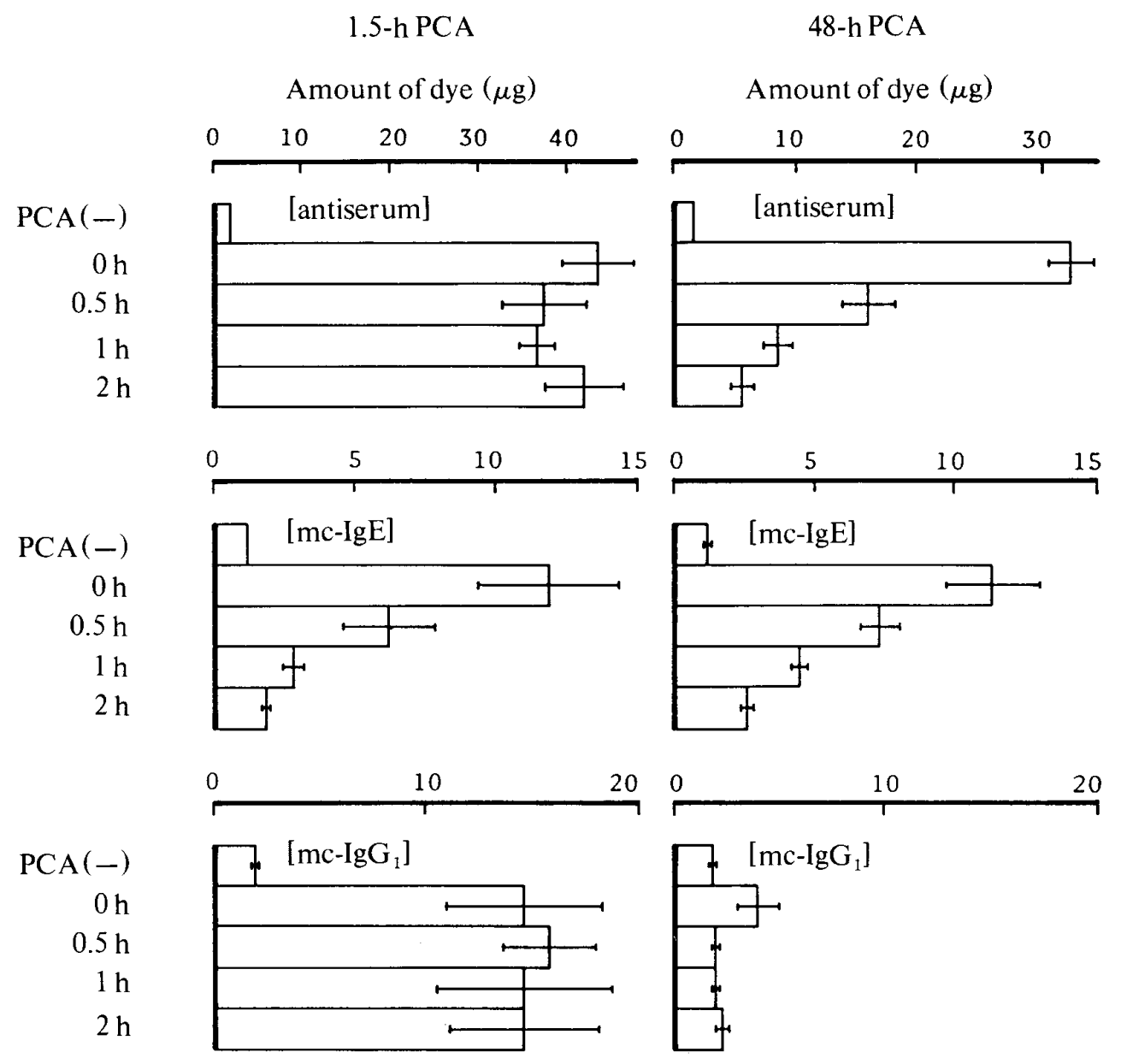

Fig. 1. Effect of Heat-Treatment of Antiserum and Monoclonal Antibodies on 1.5-h and 48-h PCA's in the Mouse Ear Antiserum and monoclonal antibodies were heated at $56{ }^{\circ} \mathrm{C}$ for $0.5,1$ or $2 \mathrm{~h}$. Each value represents the mean and the standard error of 5 or 6 mice. 

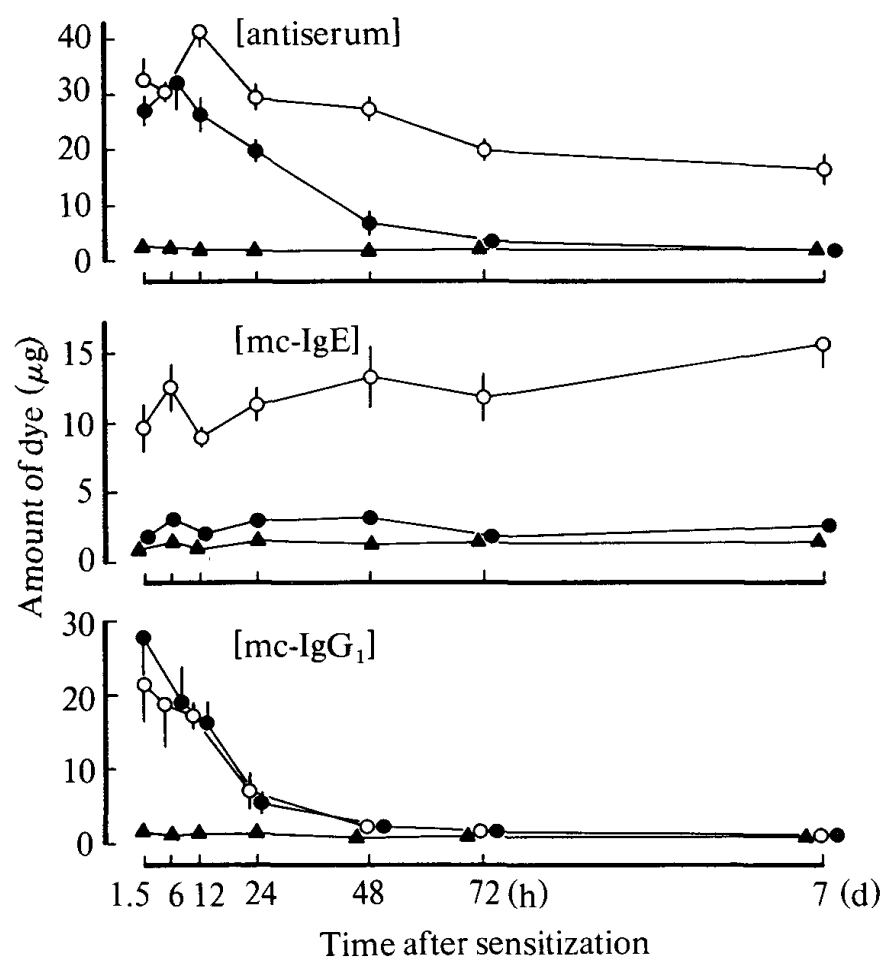

Fig. 2. Effect of Heat-Treatment of Antiserum and Monoclonal Antibodies on PCA Elicited at Various Time after Sensitization

Antiserum and monoclonal antibodies were heated at $56^{\circ} \mathrm{C}$ for $2 \mathrm{~h}$. Sensitized mice were challenged $1.5 \mathrm{~h}-7 \mathrm{~d}$ after the sensitization. Each value represents the mean and the standard error of 3-6 mice. $\bigcirc$, non-heated; heated; $\boldsymbol{\Delta}, \operatorname{PCA}(-)$.

To examine the persistence of sensitized state, mice were sensitized with a non-heated or heated sample and the PCA's were elicited 1.5 $h-7 \mathrm{~d}$ after sensitization. Heat-treatment at 56 ${ }^{\circ} \mathrm{C}$ was performed for $2 \mathrm{~h}$. The results are shown in Fig. 2. The PCA's mediated by non-heated antiserum were almost comparable to those mediated by heated antiserum at 1.5 and $6 \mathrm{~h}$, which gradually decreased thereafter. However, a potent reaction was elicited even at $7 \mathrm{~d}$, and the amount of extravasated dye was $16.57 \pm 2.64 \mu \mathrm{g}(n=5)$. On the contrary, the PCA mediated by heated antiserum reduced rapidly with the sensitizing period and the level reached were almost negligible at $48 \mathrm{~h}$. The unheated $\mathrm{mc}-\mathrm{IgE}$ caused strong reactions at all sensitizing periods and the levels did not reduce even at $7 \mathrm{~d}$. In contrast, heated mc-IgE did not elicit PCA and the level was comparable to that
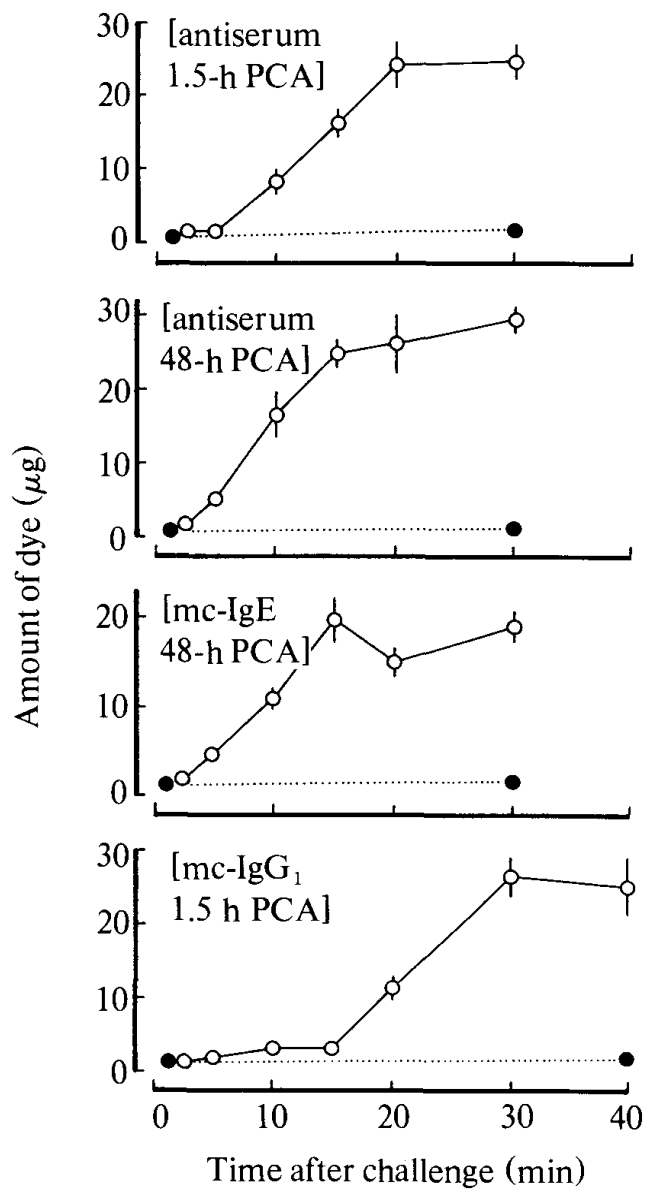

Fig. 3. Accumulation of Dye in the Mouse Ear Caused by PCA

Mice were sacrificed 2-40 min after challenge. Each value represents the mean and the standard error of 3-6 mice. Closed circle indicates PCA (-).

for each PCA (-) group. Although $m c-\operatorname{IgG}_{1}$, in both non-heated and heated forms, elicited potent PCA's at $1.5 \mathrm{~h}$, the levels reduced rapidly and completely disappeared at $48 \mathrm{~h}$. Heating of $\mathrm{mc}^{-} \mathrm{IgG}_{1}$ did not affect PCA.

\section{Accumulation of Dye in the Ear}

To compare the accumulating processes of dye in 1.5-h and 48-h PCA's, mice were sacrificed $2-40 \mathrm{~min}$ after the challenge. In the $1.5-\mathrm{h}$ PCA, antiserum and $\mathrm{mc}-\mathrm{IgG}_{1}$ were heated at 56 ${ }^{\circ} \mathrm{C}$ for 2 h. The results are shown in Fig. 3. Dye leakage in the 1.5-h PCA mediated by antiserum occurred at $10 \mathrm{~min}$ and to $20 \mathrm{~min}$ after the challenge. In contrast, in the case of the 48-h PCA mediated by antiserum, leaked dye was detected at $5 \mathrm{~min}$ and the leakage terminated $15 \mathrm{~min}$ after 


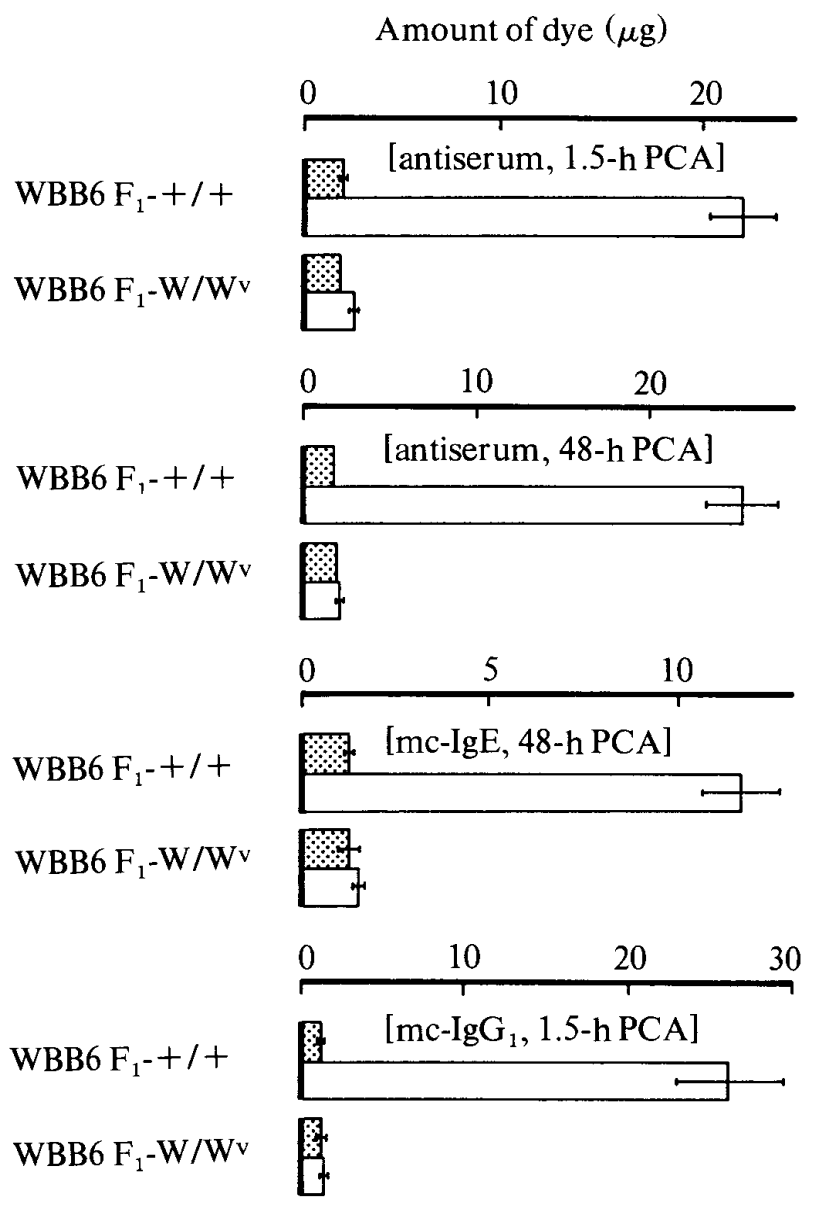

Fig. 4. The 1.5-h and 48-h PCA's in WBB6 $\mathrm{F}_{1}-+/+$ and $\mathrm{W} / \mathrm{W}^{\mathrm{v}}$ Mice

Dotted column indicates PCA (-). Each value represents the mean and the standard error of 3 (in PCA(-) group) or 5 (in PCA group) mice.

the challenge. A similar pattern was observed in the case of the 48-h PCA mediated by mc-IgE. On the contrary, dye leakage in the 1.5-h PCA mediated by $\mathrm{mc}-\mathrm{IgG}_{1}$ was delayed significantly. Leaked dye was detected at 20 to $30 \mathrm{~min}$ after the challenge.

\section{PCA in WBB6 $F_{1}$ Mice}

The 1.5-h and 48-h PCA's were investigated in WBB6 $\mathrm{F}_{1}$ mice. Antiserum and $\mathrm{mc}^{-\mathrm{IgG}_{1}}$ were heated at $56^{\circ} \mathrm{C}$ for $2 \mathrm{~h}$ for 1.5 -h PCA. Results are shown in Fig. 4. In WBB6 $\mathrm{F}_{1^{-}}+/+$mice, potent PCA's were evoked in all 4 cases. In contrast, the PCA was not elicited in any of the cases in $\mathrm{WBB} \mathrm{F}_{1}-\mathrm{W} / \mathrm{W}^{\mathrm{v}}$ mice.

\section{Effect of Tranilast}

Effect of tranilast on the 1.5-h and 48-h

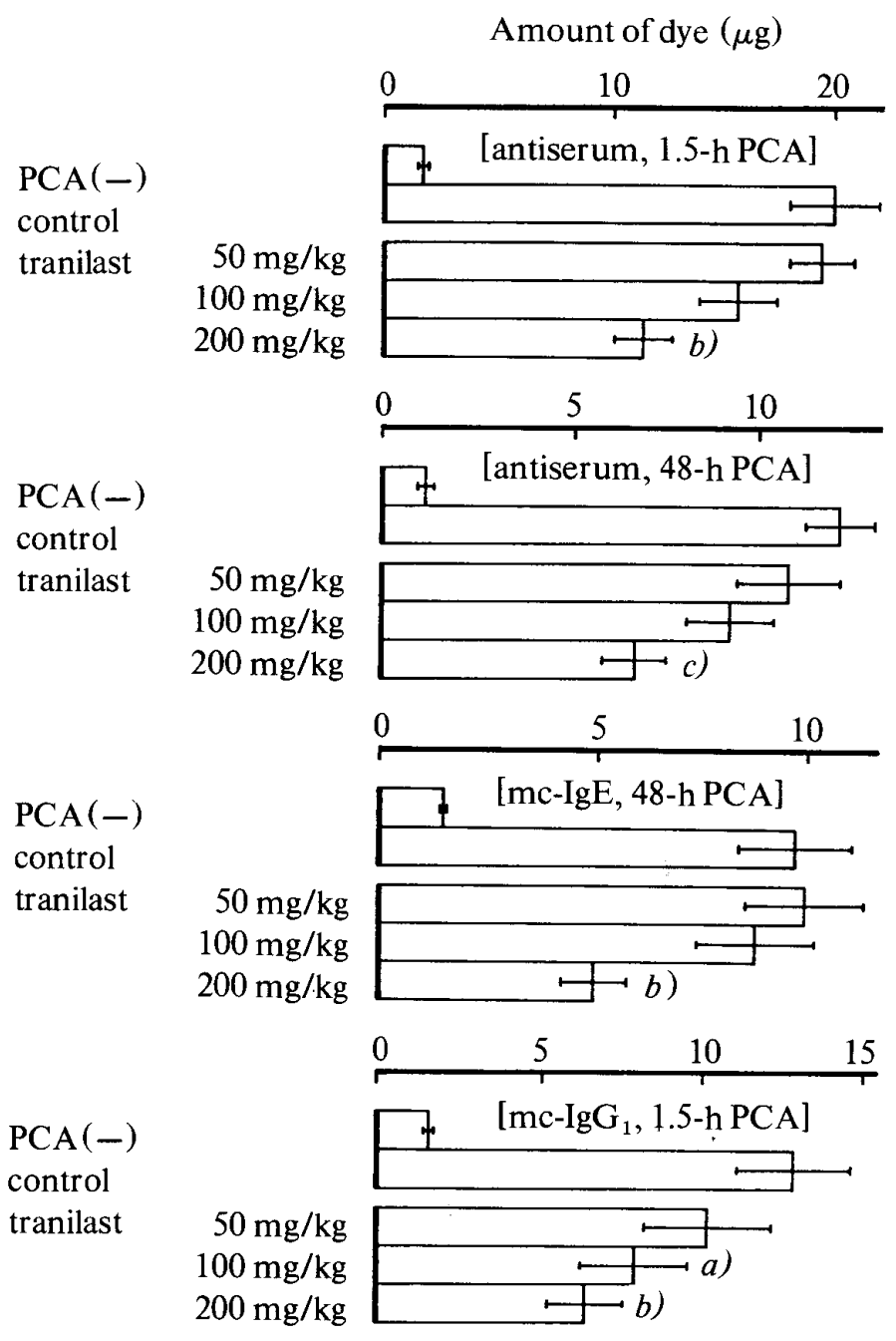

Fig. 5. Effect of Tranilast on 1.5-h and 48-h PCA's in Mouse Ear

Tranilast was suspended in distilled water containing $0.2 \%$ sodium carboxymethylcellulose and given orally $1 \mathrm{~h}$ prior to challenge. Mice fasted for $6-8 \mathrm{~h}$ before the administration. Each value represents the mean and the standard error of $4-8$ mice. a) $p<0.05, b) p<0.01, c) p<0.001$.

PCA's was investigated. In the 1.5-h PCA, antiserum and $\mathrm{mc}-\mathrm{IgG}_{1}$ were heated at $56^{\circ} \mathrm{C}$ for $2 \mathrm{~h}$. Tranilast was suspended in distilled water containing $0.2 \%$ sodium carboxymethylcellulose and given $50-200 \mathrm{mg} / \mathrm{kg}$ orally $1 \mathrm{~h}$ prior to challenge. As shown in Fig. 5, the PCA's mediated by both antiserum and monoclonal antibodies were inhibited in a dose-dependent manner and the degree of inhibition in each case was almost comparable.

\section{Absorption of Antiserum}

Antiserum was absorbed with anti- $\epsilon$-Sepha- 
Amount of dye $(\mu \mathrm{g})$

[1.5-h PCA]

$\mathrm{PCA}(-)$

control

absorbed

(1 time)

0

7. [anti- $\epsilon$-Sepharose 4B]

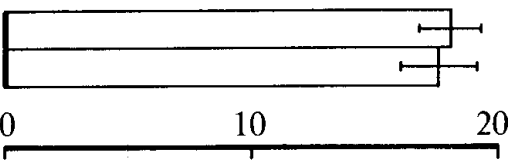

$\operatorname{PCA}(-)$

control

absorbed

(1 time)

(2 times)

(3 times)

G [anti- $\gamma_{1}$-Sepharose 4B]

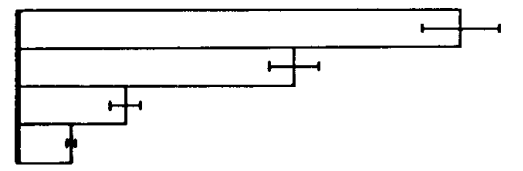

0 5

10

[48-h PCA]

$\mathrm{PCA}(-)$

control

absorbed

(1 time)

\& [anti- $\gamma_{1}-$ Sepharose 4B]

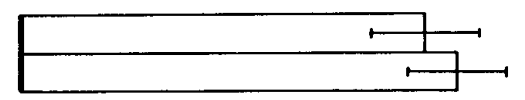

0

5

10

15

$\operatorname{PCA}(-)$

control

absorbed

(1 time)
(2 times)
(3 times)

[ [anti- $\epsilon-$ Sepharose 4B]

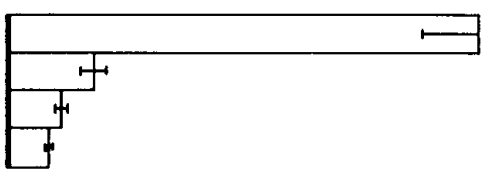

Fig. 6. Effect of Absorption of Antiserum on PCA in the Mouse Ear

Antiser um was mixed with anti- $\epsilon$-Sepharose $4 \mathrm{~B}$ or anti- $\gamma_{1}$-Sepharose $4 \mathrm{~B}$ and rotated gently for $30 \mathrm{~min}$ at room temperature. The unabsorbed fraction was concentrated and examined for the activity to elicit 1.5-h or 48-h PCA. In the 1.5-h PCA, antiserum was heated at 56 ${ }^{\circ} \mathrm{C}$ for $2 \mathrm{~h}$. Each value represents the mean and the standard error of 5-10 mice.

rose $4 \mathrm{~B}$ or anti- $\gamma_{1}-$ Sepharose $4 \mathrm{~B}$ and the activity of the unabsorbed fraction to elicit PCA was examined. In the 1.5-h PCA, antiserum was heated at $56{ }^{\circ} \mathrm{C}$ for $2 \mathrm{~h}$. As shown in Fig. 6, although absorption of heated antiserum with anti- $\epsilon$-Sepharose 4B did not affect the 1.5-h PCA, absorption with anti- $\gamma_{1}$-Sepharose $4 \mathrm{~B}$ significantly reduced the 1.5-h PCA. Repeated absorption abrogated 1.5-h PCA completely. Similarly, although absorption of non-heated antiserum with anti- $\gamma_{1}$-Sepharose $4 \mathrm{~B}$ did not affect the 48-h PCA, absorption with anti- $\epsilon$-Sepharose $4 \mathrm{~B}$ significantly reduced $48-\mathrm{h}$ PCA. When the absorption was repeated, the 48-h PCA was abrogated completely.

\section{Discussion}

In the present study, PCA's were elicited in the mouse ear sensitized with antiserum,

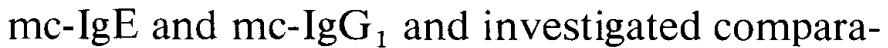
tively. In the mc-IgE-mediated PCA, sensitized state was achieved soon after the injection of the antibody and persisted at least for $7 \mathrm{~d}$. Treatment at $56{ }^{\circ} \mathrm{C}$ for $2 \mathrm{~h}$ abrogated the activity of mc- $\mathrm{IgE}$ to elicit PCA. These properties of the IgE antibody are well established. ${ }^{1-3)}$ In the case of antiserum, although sensitized state persisted at least for $7 \mathrm{~d}$, the PCA elicited 1.5-24 h after the sensitization was not abrogated by heating of antiserum at $56^{\circ} \mathrm{C}$ for $2 \mathrm{~h}$. On the other hand, the 48-h PCA was abrogated completely by the absorption of antiserum with anti- $\epsilon$-Sepharose 4B. Furthermore, the accumulation pattern of dye in the 48-h PCA mediated by non-heated antiserum was in good agreement with that in the case of mc-IgE. These results indicated that the 48-h PCA in the mouse ear caused by antiserum is mediated by the IgE antibody. In contrast, the sensitized state disappeared rapidly in cases of heated antiserum and $\mathrm{mc}^{-\mathrm{IgG}_{1}}$, and the 1.5-h PCA's mediated by antiserum and $\mathrm{mc}-\mathrm{IgG}_{1}$ were not affected by heating. Furthermore, the 1.5-h PCA mediated by heated antiserum was completely abrogated by absorption with anti- $\gamma_{1^{-}}$ Sepharose 4B. These results suggested that the $\mathrm{IgG}_{1}$ antibody mediated $1.5-\mathrm{h}$ PCA in the mouse ear sensitized with heated antiserum. However, accumulation of dye observed in mc$\mathrm{IgG}_{1}$-mediated 1.5-h PCA delayed significantly when compared to that observed in heated antiserum-mediated 1.5-h PCA. In 1982, Ovary ${ }^{21)}$ reported that mouse $\operatorname{IgG}_{2 \mathrm{a}}$ and $\mathrm{IgG}_{2 \mathrm{~b}}$ antibodies sensitize homologous skin for PCA. In fact, it must be considered that diluted antiserum for sensitization also contains many serum components, except for $\operatorname{IgG}_{1}$ antibody, and that $1.5 \mathrm{~h}$ may be too short for these serum components to disappear from injection sites. Therefore, the difference observed in the accumulation of dye between the 1.5-h PCA's mediated by heated antiserum and $\mathrm{mc}^{-\mathrm{IgG}_{1}}$ may be explained by participation of other serum components in antiserum-mediated PCA. However, the precise mechanism is not clear, and further 
characterization of the 1.5-h PCA caused by the $\mathrm{IgG}_{1}$ antibody must be undertaken using other monoclonal $\mathrm{IgG}_{1}$ antibody preparations.

It is well established that mast cells have many receptors for the Fc portion of the IgE antibody $(F c \in R)$ on their surface and that the IgE antibody binds strongly to $F c \epsilon R .{ }^{22)}$ When sensitized mast cells are challenged with a specific antigen, two or more IgE antibody molecules on the mast cell surface are linked together by an antigen molecule. ${ }^{10,23)}$ This crosslinkage is an essential process for $\mathrm{IgE}$ antibody-mediated mast cell activation, and degranulation and mediator release are evoked within a very short time. In PCA, vascular permeability is increased by released mediators as a result. In contrast, though the IgG homocy totropic antibody causes an anaphylactic reaction similar to that caused by the IgE antibody, the mechanism is not fully understood. Nakagawa and de Weck ${ }^{24)}$ indicated the presence of membrane receptors for $\mathrm{IgG}_{4}$ subclass on human basophils and mast cells. However, in mice, the affinity of the receptor to the $\operatorname{IgG}_{1}$ antibody is considered to be low $^{25)}$ and its role in $\mathrm{IgG}_{1}$ antibody-mediated reaction is not yet established.

In the present results with WBB6 $F_{1}-W / W^{v}$ mice which lack mast cells ${ }^{26)}$ and with tranilast which inhibits mediator release from mast cells, ${ }^{19,20)}$ it was indicated that the mast cell is essential not only for the 48-h PCA's mediated by antiserum and mc-IgE but also for 1.5-h PCA's caused by heated antiserum and $\mathrm{mc}^{-\operatorname{IgG}_{1}}$. Tranilast dose not exhibit antagonistic effect against mediators from mast cells. On the other hand, the dye leakage was confirmed from 5 min to 15 min after challenge in the 48-h PCA's mediated by both antiserum and mc-IgE. On the contrary, the dye leakage in the 1.5-h PCA was delayed when compared to that of the 48-h PCA and the delay was about $5 \mathrm{~min}$ in antiserum-mediated PCA and about $15 \mathrm{~min}$ in $\mathrm{mc}-\mathrm{IgG}_{1}$-mediated PCA. It is considered that the rapid initiation and termination of dye leakage in the 48-h PCA was caused by the direct activation of mast cells via $\mathrm{Fc} \in \mathrm{R}$. The delay observed in the 1.5-h PCA may be explained by the involvement of indirect process in $\mathrm{IgG}_{1}$ antibody-mediated mast cell activation. As Binaghi ${ }^{25)}$ stressed the importance of the formation of immune complex in $\operatorname{IgG}_{1}$ antibody-mediated reaction in vitro, the mast cell may be activated secondarily in $\mathrm{IgG}_{1}$ antibody-mediated 1.5-h PCA in the mouse ear.

\section{References}

1) I. Mota and J. M. Peixoto: A skin sensitizing and thermolabile antibody in the mouse, Life Sci., 5, $1723-1728$ (1966)

2) R. Revoltella and Z. Ovary: Reaginic antibody production in different mouse strains, Immunology, 17, 45-54 (1969).

3) E. M. Vaz, I. H. S. Silveira, V. M. B. Dodd, M. R. Monteiro and N. M. Vaz: Anaphylactic antibodies in the mouse. Relationship to mast cell degranulation during in vivo anaphylactic reactions, Int. Arch. Allergy Appl. Immunol., 39, 459-468 (1970).

4) M. K. Bach, K. L. Block and K. F. Austen: IgE and IgG antibody-mediated release of histamine from rat peritoneal cells. I. Optimum conditions for in vitro preparation of target cells with antibody and challenge with antigen, J. Exp. Med., 133, 752-784 (1971).

5) B. B. Levine, H. Chang Jr. and N. M. Vaz: The production of hapten-specific reaginic antibodies in the guinea pig, J. Immunol., 106, 29-33 (1971).

6) N. J. Zvaifler and E. L. Becker: Rabbit anaphylactic antibody, J. Exp. Med., 123, 935-950 (1966).

7) K. Lindquist: A unique class of rabbit immunoglobulins eliciting passive cutaneous anaphylaxis in homologous skin, Immunochemistry, 5, 525-542 (1968).

8) K. Ishizaka, H. Tomioka and T. Ishizaka: Mechanisms of passive sensitization. I. Presence of $\operatorname{IgE}$ and $\mathrm{IgG}$ molecules on human leukocytes, J. Immunol., 105, 1459- 1467 (1970).

9) T. Ishizaka and K. Ishizaka: Triggering of histamine release from rat mast cells by divalent antibodies against IgE-receptors, J. Immunol., 120, 800-805 (1978).

10) T. Ishizaka: Analysis of triggering events in mast cells for immunoglobulin E-mediated histamine release, $J$. Allergy Clin. Immunol., 67, 90-96 (1981).

11) R. C. Aalberse, P. H. Dieges, V. Knul-Bretlova, P. Vooren, M. Aalbers and J. van Leeuwen: $\operatorname{IgG}_{4}$ as a blocking antibody, Clin. Rev. Allergy, 1, 289-302 (1983).

12) J. G. Feinberg: Pinnal anaphylaxis: An additional anaphylactic site, Nature (London), 191, 712 (1961).

13) A. Prouvost-Danon and R. Binaghi: Reaginic antibody in adult and young mice. Production and biological properties, Int. Arch. Allergy Appl. Immunol., 38, 648-656 (1970).

14) N. Inagaki, S. Goto, H. Nagai and A. Koda: Mouse ear PCA as a model for evaluating antianaphylactic agents, Int. Arch. Allergy Appl. Immunol., 74, 91-92 (1984).

15) N. Inagaki, S. Goto, M. Yamasaki, H. Nagai and A. Koda: Studies on vascular permeability increasing factors involved in 48-hour homologous PCA in the 
mouse ear, Int. Arch. Allergy Appl. Immunol., 80, 285-290 (1986).

16) N. Inagaki, S. Goto, H. Nagai and A. Koda: Homologous PCA in various'strains of mice, Int. Arch. Allergy Appl. Immunol., 81, 58-62 (1986).

17) N. Watanabe and Z. Ovary: Antigen and antibody detection by in vivo methods; a reevaluation of passive cutaneous anaphylactic reactions, J. Jmmunol. Methods, 14, 381-390 (1977).

18) H. N. Eisen, S. Belman and M. E. Carsten: The reaction of 2,4-dinitrobenzenesulfonic acid with free amino groups of proteins, J. Am. Chem. Soc., 75, 4583-4585 (1953).

19) A. Koda, H. Nagai, S. Watanabe, Y. Yanagihara and K. Sakamoto: Inhibition of hypersensitivity reactions by a new drug, $N\left(3^{\prime}, 4^{\prime}\right.$-dimethoxycinnamoyl) anthranilic acid $\left(N-5^{\prime}\right)$, J. Allergy Clin. Immunol., 57, 396-40', (1976).

20) H. Azuma, K. Banno and T. Yoshimura: Parmacological properties of $N$ - $\left(3^{\prime}, 4^{\prime}\right.$-dimethoxycinnamoyl)anth- ranilic acid $\left(N-5^{\prime}\right)$, a new anti-atopic agent, $B r . J$. Pharmacol., 58, 483-488 (1976).

21) Z. Ovary: Recent insight into class-speciñc properties of murine immunoglobulins obtained with the help of monoclonal antibodies, Int. Arch. Allergy Appl. Immunol., 69, 385-392 (1982).

22) A. R. Sterk and T. Ishizaka: Binding properties of $\operatorname{IgE}$ receptors on normal mouse mast cells, J. Immunol., 128, 838-843 (1982).

23) A. Kagey-Sobotka, D. W. MacGlashan and L. M. Lichtenstein: Role of receptor aggregation in triggering IgEmediated reactions, Fed. Proc., 41, 12-16 (1982).

24) T. Nakagawa and A. L. de Wech: Membrane receptors for the IgG subclass on human basophils and mast cells, Clin. Rev. Allergy, 1, 197-206 (1983).

25) R. A. Binaghi: Nonreaginic anaphylactic antibodies in animals, Clin. Rev. Allergy, 1, 237-247 (1983).

26) Y. Kitamura, S. Go and K. Hatanaka: Decrease of mast cells in $\mathrm{W} / \mathrm{W}^{\mathrm{v}}$ mice and their increase by bone marrow transplantation, Blood, 52, 447-452 (1978). 